\title{
STUDIES ON THE RENAL CONCENTRATING MECHANISM. IV. OSMOTIC DIURESIS*
}

\author{
By LAWRENCE G. RAISZ, † WILLIAM Y. W. AU $\ddagger$ AND ROBERT L. SCHEER \\ (From the Medical Service, Veterans Administration Hospital, and Department of Medicine, \\ State University of New York, Upstate Medical Center, Syracuse, N. Y.)
}

(Submitted for publication April 29, 1959; accepted June 5, 1959)

Studies of osmotic diuresis in the hydropenic state have demonstrated a decrease in urine solute concentration as urine flow increases $(1,2)$ but the physiologic mechanism of this decrease is not fully understood. Although concentrating ability appears to be limited by a maximal osmotic urine/plasma $(\mathrm{U} / \mathrm{P})$ ratio, small increases in solute excretion have been shown to lead to a decrease in osmotic $U / P$ ratio even when urine flow remains less than $2 \mathrm{ml}$. per minute (3). At high flows, when there is a marked decrease in osmotic $U / P$ ratio, there is evidence that the concentrating mechanism may be limited by a constant maximal rate of net water reabsorption $\left(\mathrm{T}^{\mathrm{c}}{ }_{\mathrm{m}_{2} \mathrm{O}} \mathrm{O}\right)$ (4). In the present study the response to osmotic diuresis has been examined over a wide range of urine flow in multiple experiments in the same subject. As urine flow increased up to $20 \mathrm{ml}$. per minute per $1.73 \mathrm{M} .^{2}$ there was a consistent curvilinear decrease in $U / P$ ratio and a curvilinear increase in net water reabsorption $\left(\mathrm{T}^{\mathrm{c}} \mathrm{H}_{2} \mathrm{O}\right)$. These curves could be described by simple reciprocal equations from which maximal values for $U / P$ ratio and for $T^{\circ}{ }_{\mathrm{H}_{2} \mathrm{O}}$ could be predicted.

It has been suggested that the response of the concentrating mechanism to urea diuresis differs from that obtained with other osmotic diuretics (5-8). By the present method of analysis the response to urea and mannitol loading did not differ at intermediate rates of urine flow. At very high flows, on the other hand, the curvilinear relationship between urine flow and concentrating response was disrupted so that $\mathrm{T}^{\mathbf{c}_{2}} \mathrm{H}_{2} \mathrm{O}$ decreased with isotonic mannitol loading and increased with urea loading, while hypertonic mannitol loading gave intermediate values.

* Presented in part before the Annual Meeting of the American Federation for Clinical Research, Atlantic City, N. J., May 4, 1958.

† Veterans Administration Clinical Investigator.

$\ddagger$ Life Insurance Medical Research Fund Fellow 19581959.

\section{METHODS}

The subjects were healthy young men who had demonstrated an ability to empty their bladder consistently at low rates of urine flow. The subjects were deprived of water for 18 to 20 hours prior to each experiment and given a dry supper and no breakfast. Solute loading was begun in the morning after two or three preliminary urine collection periods, and was generally maintained at a constant rate for two or more hours in order to obtain data during a steady state. Subsequent analysis indicated that data obtained with steady, increasing and decreasing rates of urine flow were sufficiently similar to be pooled. Aberrant values were obtained in the initial period after loading when urine flow increased more than twofold and these periods were discarded. The solutions of urea or mannitol used for intravenous loading also contained sodium chloride in concentrations of 0.1 to 0.7 per cent to minimize sodium losses. Hence all infusions were actually hypertonic to plasma. Sufficient vasopressin was added to provide 200 milliunits per hour, except at the highest rates of urine flow (more than $20 \mathrm{ml}$. per minute) when the dose of vasopressin was increased to 600 milliunits per hour. The following types of experiments were performed:

1. Isotonic mannitol loading. Five per cent mannitol was infused at rates of 3 to $20 \mathrm{ml}$. per minute with a constant infusion pump or at rates of 40 to $80 \mathrm{ml}$. per minute by gravity using a large bore needle.

2. Hypertonic mannitol loading. Fifteen per cent mannitol was infused at 10 or $20 \mathrm{ml}$. per minute by a constant infusion pump. Initial loading with hypertonic mannitol led to severe postural headache and therefore this infusion was given only after a diuresis had first been established by infusing isotonic mannitol at $20 \mathrm{ml}$. per minute for two hours.

3. Urea loading. Thirty per cent urea was infused at 1 to $2 \mathrm{ml}$. per minute. A few attempts at more rapid administration led to severe postural headache and nausea.

4. Urea plus mannitol loading. In order to compare the effects of urea and mannitol at high urine flow, 6 per cent urea in 5 per cent mannitol was infused at $20 \mathrm{ml}$. per minute.

Chemical methods have been described previously (3). All data were corrected to $1.73 \mathrm{M}^{2}$ of body surface area. Concentrating ability is evaluated both in terms of the osmotic $\mathrm{U} / \mathrm{P}$ ratio and in terms of net water reabsorption, $\mathrm{T}^{\mathrm{T}} \mathrm{H}_{\mathbf{2}} \mathrm{O}$, calculated as follows :

$$
\mathrm{T}_{\mathrm{H}_{2} \mathrm{O}}=\frac{\mathrm{U}_{\mathrm{osm}} \mathrm{V}}{\mathrm{P}_{\mathrm{osm}}}-\mathrm{V} \text {. }
$$

$\mathrm{U}_{\text {oem }} \mathrm{V} / \mathrm{P}_{\text {oom }}$ represents the volume of fluid that would 
TABLE I

Relationship between urine flow $(V)$, osmotic urine/plasma ratio $(U / P)$ and net water reabsorption $\left(T^{c} \mathrm{H}_{2} \mathrm{O}\right)$ during osmotic diuresis*

\begin{tabular}{|c|c|c|c|c|c|c|c|c|c|c|c|}
\hline \multirow{2}{*}{$\begin{array}{l}\text { Subject, age, } \\
\text { surface area }\end{array}$} & \multirow{2}{*}{$\begin{array}{l}\text { No. of } \\
\text { periods }\end{array}$} & \multicolumn{3}{|c|}{ Range of values } & \multirow[b]{2}{*}{$\mathbf{a}$} & \multirow[b]{2}{*}{ b } & \multirow[b]{2}{*}{$\mathbf{r}$} & \multirow{2}{*}{$\begin{array}{l}\text { Predicted } \\
\text { T०maxH } 90\end{array}$} & \multirow{2}{*}{$\begin{array}{c}\text { Actual } \\
\text { Tomax日gO }\end{array}$} & \multirow{2}{*}{$\begin{array}{l}\text { Predicted } \\
\text { U/P max }\end{array}$} & \multirow{2}{*}{$\begin{array}{l}\text { Actual } \\
\text { U/P max }\end{array}$} \\
\hline & & $\mathbf{v}$ & $\mathrm{U} / \mathrm{P}$ & $\mathrm{T}^{\circ} \mathrm{H}_{2} \mathrm{O}$ & & & & & & & \\
\hline & \multicolumn{5}{|c|}{$\operatorname{ml} . / \min . / 1.73 \mathrm{M} .^{2}$} & \multicolumn{6}{|c|}{$\operatorname{ml} . / \min . / 1.73 \mathrm{M.} .^{2}$} \\
\hline Pooled data $\dagger$ & & & & & & & & & & & \\
\hline $\begin{array}{l}\text { M. G., 25, } 1.90 \mathrm{M}^{2} \\
\text { P. M., 25, 1.98 M.2 } \\
\text { A. M., 23, 1.59 M.2 }\end{array}$ & $\begin{array}{l}63 \\
47 \\
52\end{array}$ & $\begin{array}{l}1.9-19.3 \\
1.9-19.7 \\
2.0-19.4\end{array}$ & $\begin{array}{l}2.8-1.4 \\
3.0-1.3 \\
2.9-1.3\end{array}$ & $\begin{array}{l}3.3-9.0 \\
3.4-7.7 \\
3.5-7.5\end{array}$ & $\begin{array}{l}.106 \\
.126 \\
.138\end{array}$ & $\begin{array}{l}.391 \\
.282 \\
.250\end{array}$ & $\begin{array}{l}.985 \\
.980 \\
.978\end{array}$ & $\begin{array}{l}9.43 \\
7.94 \\
7.25\end{array}$ & $\begin{array}{l}9.32 \\
7.88 \\
7.24\end{array}$ & $\begin{array}{l}3.56 \\
4.55 \\
5.00\end{array}$ & $\begin{array}{l}4.18 \\
3.96 \\
4.43\end{array}$ \\
\hline \multicolumn{12}{|l|}{ Individual expts. $\ddagger$} \\
\hline $\begin{array}{l}\text { J.F., 34, } 2.04 \mathrm{M.}^{2} \\
\text { W.A., 28, } 1.55 \mathrm{M.}^{2} \\
\text { R. F., 25, 2.06 M.2 } \\
\text { J. P., 26, } 1.90 \mathrm{M.}^{2}\end{array}$ & $\begin{array}{l}15 \\
21 \\
12 \\
12\end{array}$ & $\begin{array}{l}4.5-17.4 \\
1.8-17.1 \\
3.6-14.3 \\
3.7-9.6\end{array}$ & $\begin{array}{l}1.9-1.3 \\
2.5-1.3 \\
2.3-1.5 \\
2.2-1.6\end{array}$ & $\begin{array}{l}3.8-6.6 \\
2.9-4.5 \\
4.7-7.1 \\
4.4-6.1\end{array}$ & $\begin{array}{l}.137 \\
.204 \\
.114 \\
.124\end{array}$ & $\begin{array}{l}.554 \\
.290 \\
.505 \\
.409\end{array}$ & $\begin{array}{l}.980 \\
.987 \\
.974 \\
.990\end{array}$ & $\begin{array}{l}7.30 \\
4.90 \\
8.77 \\
8.07\end{array}$ & $\begin{array}{l}6.42 \\
5.26\end{array}$ & $\begin{array}{l}2.81 \\
4.49 \\
2.98 \\
3.45\end{array}$ & $\begin{array}{l}3.54 \\
3.82 \\
4.53 \\
4.37\end{array}$ \\
\hline
\end{tabular}

* The regression constants $(a$ and $b)$ and the correlation coefficient ( $r$ ) are given for Equation 2. Predicted $T^{\circ} \max _{\mathrm{H}_{2} \mathrm{O}}$ and $\mathrm{U} / \mathrm{P}$ max are calculated from Equations 2 and 3 and compared with actual maximum values obtained in the same subjects at urine flows greater than 20 and less than $0.5 \mathrm{ml}$. per minute per $1.73 \mathrm{M.} .^{2}$, respectively.

$\dagger$ Data from five or more loading experiments including isotonic mannitol, hypertonic mannitol, urea, and urea plus mannitol.

$\ddagger$ Isotonic mannitol loading in J. F. and W. A., hypertonic mannitol loading in R. F. and J. P.

contain the urinary solutes in a solution isosmotic with the plasma, the osmolal clearance $\left(\mathrm{C}_{\mathrm{osm}}\right)$. If net water reabsorption is the final operation in urine formation, then $\mathrm{C}_{\text {osm }}$ can be considered to represent the load of isotonic fluid delivered from the distal tubule to the concentrating site and $\mathrm{T}^{{ }^{\circ}} \mathrm{H}_{2} \mathrm{O}$ the reabsorptive activity at that site. Since there is recent evidence that solute transport occurs even in the terminal portions of the collecting system (9), it may not be exact to equate $\mathrm{C}_{\text {osm }}$ with load but $\mathrm{T}^{\circ}{ }_{\mathrm{H}_{2} \mathrm{O}}$ is still a measure of net water economy. The statistical methods used are described by Snedecor (10).

\section{RESULTS}

As urine flow increased from 2 to $20 \mathrm{ml}$. per minute per $1.73 \mathrm{M} .^{2}$ during osmotic diuresis, there was a curvilinear decrease in osmotic $U / P$ ratio, and an increase in $\mathrm{T}_{\mathrm{H}_{2} \mathrm{O}}$ (Figure 1). Pooled data for multiple experiments in the same subject showed relatively little scatter, so that it appeared feasible to fit these curves to a single regression equation. The most linear representation of the data was consistently obtained when the reciprocal $\frac{1}{\mathrm{U} / \mathrm{P}-1}$ was plotted against $\mathrm{V}$ (Figure 1). The regression equation for this relationship:

$$
\frac{1}{\mathrm{U} / \mathrm{P}-1}=\mathrm{aV}+\mathrm{b}
$$

was calculated by the method of least squares. ${ }^{1}$ From this equation it can be predicted that as $\mathrm{V}$ approaches zero, osmotic $\mathrm{U} / \mathrm{P}$ ratio should approach a limiting maximum value (U/P max)

\footnotetext{
1 This equation was derived empirically. For theoretical basis, see discussion.
}

which will depend on the value of the constant $b$ $\left(\mathrm{U} / \mathrm{P} \max =\frac{1}{\mathrm{~b}}+1\right)$. Dividing Equation 2 by $\mathrm{V}$ and substituting Equation 1 we obtain:

$$
\frac{1}{\mathrm{~T}^{\mathrm{c}} \mathrm{H}_{2} \mathrm{O}}=\mathrm{a}+\frac{\mathrm{b}}{\mathrm{V}} \text {. }
$$

This equation predicts that as $\mathrm{V}$ increases, $\mathrm{T}^{\circ}{ }_{\mathrm{H}_{2} \mathrm{O}}$ will approach a maximum value $\left(\mathrm{T}^{\mathrm{c}} \max _{\mathrm{H}_{2} \mathrm{O}} \mathrm{O}\right.$ which will depend on the value of the constant $a$ $\left(\mathrm{T}^{\mathrm{c}} \max _{\mathrm{H}_{2} \mathrm{O}}=\frac{1}{\mathrm{a}}\right)$. These equations provide a description of the relationship between flow and concentrating ability over a wide range of urine flow. Using Equation 2 various groups of data could be compared in terms of their regression constants, or from $\mathrm{U} / \mathrm{P} \max$ and $\mathrm{T}^{\mathrm{c}} \mathrm{max}_{\mathrm{H}_{2} \mathrm{O}}$ since the latter are directly derived from these constants. Table I gives these values for the subjects of Figure 1, and for individual experiments over a wide range of urine flow in four additional subjects. The correlation coefficients are uniformly high and the values of $\mathrm{T}^{\circ} \mathrm{max}_{\mathrm{H}_{2} \mathrm{O}}$ show good agreement with the highest values of $\mathrm{T}^{\circ}{ }_{\mathrm{H}_{2} \mathrm{O}}$ actually attained in the same subjects at urine flows of $20 \mathrm{ml}$. per minute or more. The maximal $\mathrm{U} / \mathrm{P}$ ratios obtained in these subjects were quite uniform while the predicted values showed greater variation.

In a previous study (3) differences in the response to urea and mannitol loading were observed at very low urine flows but these differences were associated with variations in the $U / P$ 

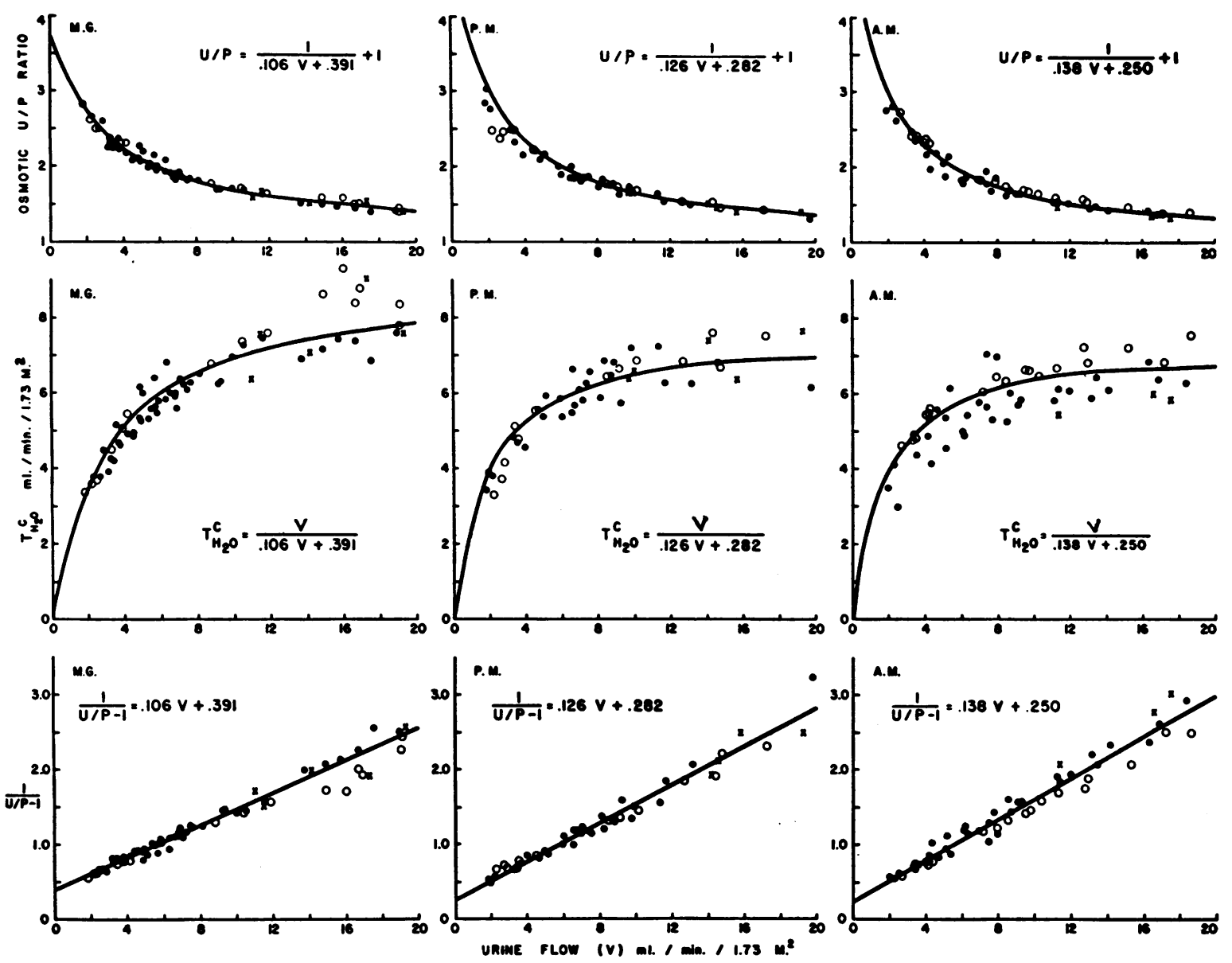

Fig. 1. Concentrating Response at Urine Flows (V) UP to 20 ML. Per Minute Per 1.73 M.2 in Three Subjects During Loading with Isotonic Mannitol, Urea and Hypertonic Mannitol

- Isotonic mannitol; $\bigcirc$ urea; $\times$ hypertonic mannitol. Equation 2 relating $\frac{1}{\mathrm{U} / \mathrm{P}-1}$ to $\mathrm{V}$, calculated by the method of least squares, is represented in the lowest graph, and rearranged to give the relationship between $U / P$ or $\mathrm{T}^{\circ} \mathrm{H}_{2} \mathrm{O}$ and $\mathrm{V}$ in the upper graphs.

ratio attained prior to loading. In the present study five pairs of experiments were obtained in which $\mathrm{U} / \mathrm{P}$ ratios were similar prior to loading (Table II, Figure 2), although the range of urine flow during loading was greater with mannitol diuresis. Sufficient data were obtained at intermediate urine flows in each experiment to calculate the regression equation 2. By analysis of co-variance (10) the values of $\frac{1}{\mathrm{U} / \mathrm{P}-1}$ were analyzed for the effects of changing urine flow (regression), for random deviations from regression and for differences in the effect of urea and mannitol loading (adjusted means). While dif- ferences in regression (represented in Table II by differences in $\mathrm{T}^{\mathrm{c}} \max _{\mathrm{H}_{2} \mathrm{O}}$ ) were probably significant on the paired experiments on Subjects P. M. and A. M., these were in opposite directions in the two subjects. The experiment in which the highest urine flow was achieved with urea loading (T. T. No. 2) showed a greater concentrating response to urea than to mannitol loading which was statistically highly significant. In terms of osmotic $\mathrm{U} / \mathrm{P}$ ratio, the mean difference was only 0.16 . Differences as large as this at intermediate urine flows have been observed in the response to repeated isotonic mannitol infusions in the same subject (see A. M., Figure 


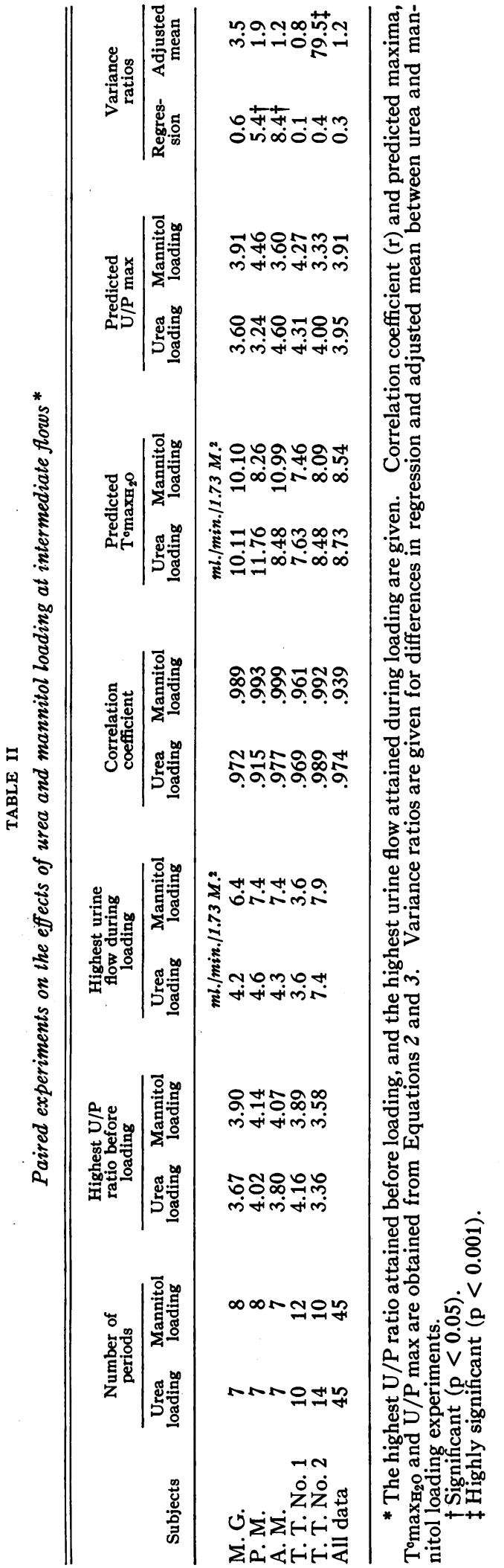

1). The pooled data show no significant difference between responses to urea and mannitol loading.

In contrast to these data, the response at higher rates of urine flow appeared to vary with the type of solute loading employed (Figures 1, 3 and 4). When isotonic mannitol was infused at rates up to $80 \mathrm{ml}$. per minute, urine flow could be increased to values as high as $50 \mathrm{ml}$. per minute per $1.73 \mathrm{M} .^{2}$. In five of six such experiments $\mathrm{T}^{\mathrm{c}}{ }_{\mathrm{H}_{2} \mathrm{O}}$ decreased progressively as urine flow increased from 15 to $40 \mathrm{ml}$. per minute per $1.73 \mathrm{M} .{ }^{2}$. In Subjects A. M., W. A., and J. F., the values for $\mathrm{T}^{\mathrm{c}} \mathrm{H}_{2} \mathrm{O}$ obtained during a massive infusion of isotonic mannitol were distinctly lower than values obtained in other experiments when the same rate of urine flow was reached by slowly increasing the rate of mannitol infusion. In three subjects urea was added to an isotonic mannitol infusion (Figure 3). Two experiments had to be discontinued because of symptoms of postural headache and nausea, but in each instance concentrating ability was greater with urea plus mannitol loading than with massive isotonic mannitol infusions at comparable rates of urine flow. When hypertonic mannitol solutions were infused, concentrating ability was greater than with isotonic mannitol in two subjects and $\mathrm{T}^{\mathrm{c}} \mathrm{H}_{2} \mathrm{O}$ appeared to be fairly constant over a wide range of urine flow.

Data on plasma and urine composition for intermediate and high flow experiments are summarized in Table III. At peak flow the sum of urinary urea, mannitol, and sodium with its anion, accounted for 96 to 99 per cent of total solute. The urine urea concentration ranged from 500 mMoles per $\mathrm{L}$. during urea loading at intermediate flows to $12 \mathrm{mMoles}$ per L. during mannitol loading at high flows.

\section{DISCUSSION}

The present analysis of the response of the renal concentrating mechanism to osmotic diuresis has yielded an equation relating osmotic $U / P$ ratio and urine flow, Equation 2, which can be rewritten as follows:

$\frac{1}{\left(\mathrm{~T}^{\mathrm{c}} \mathrm{H}_{2} \mathrm{O}\right)}=\frac{1}{\left(\mathrm{~T}^{\mathrm{c}} \max _{\mathrm{H}_{2} \mathrm{O}}\right)}+\frac{1}{(\mathrm{U} / \mathrm{P} \max -1)} \frac{1}{\mathrm{~V}}$.

This equation closely resembles the Line- 


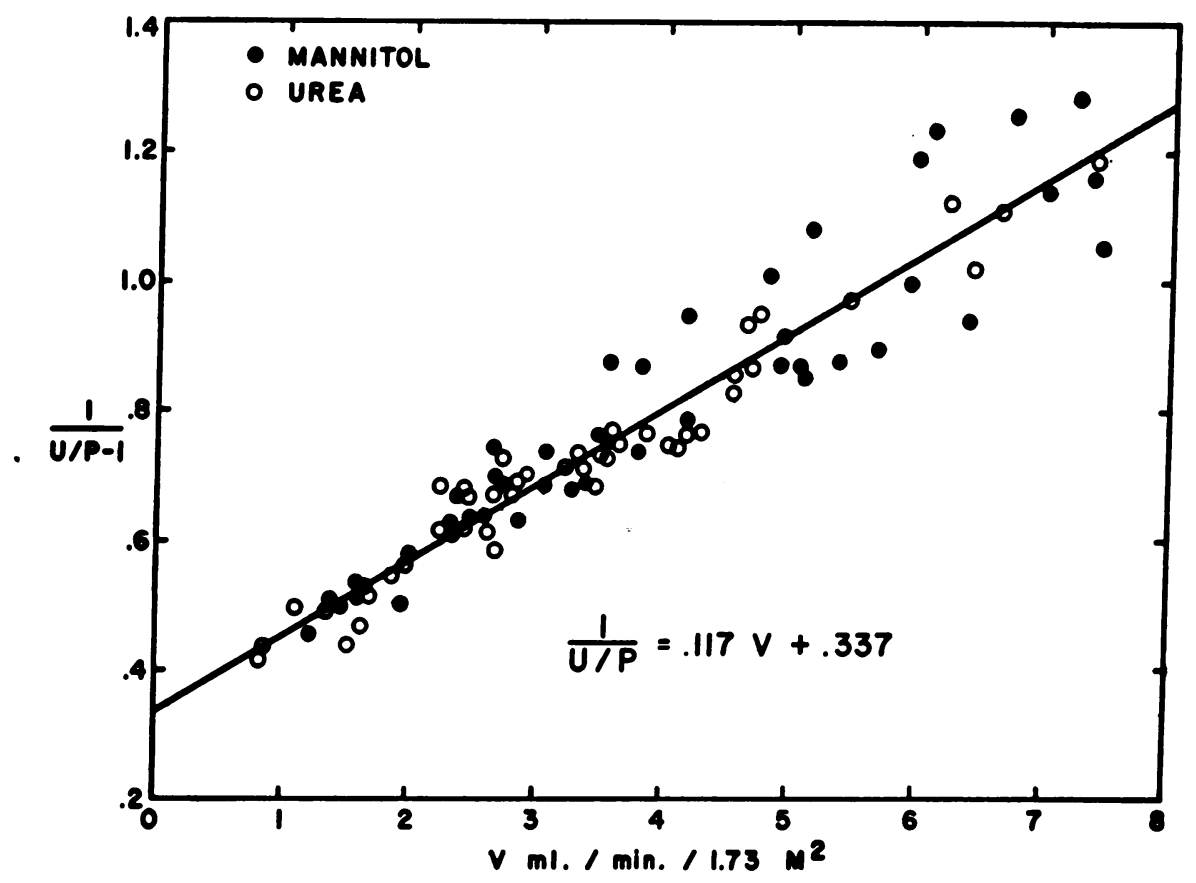

Fig. 2. Concentrating Response to Urea and Mannitol Loads at Intermediate Flows Symbols as in Figure 1.

weaver-Burk modification (11) of the classical Michaelis-Menten equation for the description of enzyme kinetics. Thus $\mathrm{T}^{\mathrm{c}} \mathrm{H}_{2} \mathrm{O}$ would represent a reaction velocity and $\mathrm{V}$ would represent substrate concentration, with $\mathrm{T}^{\mathrm{c}} \max _{\mathrm{H}_{2} \mathrm{O}}$ and $\mathrm{U} / \mathrm{P}$ max representing velocity and concentration maxima, respectively. ${ }^{2}$ This analogy need not imply that urine is concentrated by enzymatic active reabsorption of water. There is evidence

\footnotetext{
${ }^{2}$ In the original analysis of this relationship $(12,13)$ $\mathrm{C}_{\text {osm }}$ was taken as a measure of "substrate" and the "Michaelis-Menten equation" was written:
}

$$
\frac{1}{\mathrm{~T}^{\circ} \mathrm{H}_{2} \mathrm{O}}=\frac{1}{\mathrm{a}^{\prime}}+\frac{\mathrm{b}^{\prime}}{\mathrm{C}_{\mathrm{osm}}}
$$

in which $\mathrm{T}^{{ }^{6}} \mathrm{H}_{2} \mathrm{O}$ and $\mathrm{C}_{\mathrm{osm}}$ are as described above and $\mathrm{a}^{\prime}$ and $\mathbf{b}^{\prime}$ are constants. For statistical analysis the derived terms were transformed into directly measured terms yielding the expression:

$$
V=\frac{a^{\prime}}{\frac{U}{P}-1}-\frac{a^{\prime} b^{\prime}}{\frac{U}{P}}
$$

The correlation between $\mathrm{V}$ and $\frac{1}{\mathrm{U} / \mathrm{P}-1}$ was not improved by including the third term $\frac{1}{\mathrm{U} / \mathrm{P}}$, so that the simpler expression of Equation 2 was selected for further use. to suggest that the urine is concentrated by the passive reabsorption of water through the collecting ducts into a hypertonic peritubular space $(5,14-16)$. The manner in which this hypertonicity is achieved is not certain but it presumably requires active sodium transport (17). It is therefore possible that the resemblance of the equation describing the concentrating mechanism to a Michaelis-Menten equation is a reflection of the limitations imposed on the concentrating mechanism by an enzyme system involved in sodium transport. On the other hand, the equations relating water reabsorption and urine flow are also analogous to the Langmuir adsorption isotherm $(18,19)$. This equation describes the adsorption of gases but may have application to osmotic transport of solvents in which the initial step may be represented as an adsorption of the solvent on a semipermeable membrane (20). Passive osmotic transfer could thus be limited by the osmotic gradient at low flows and by the tubular adsorbing surface area at high flows. The equations relating concentrating response to urine flow are merely descrip- 

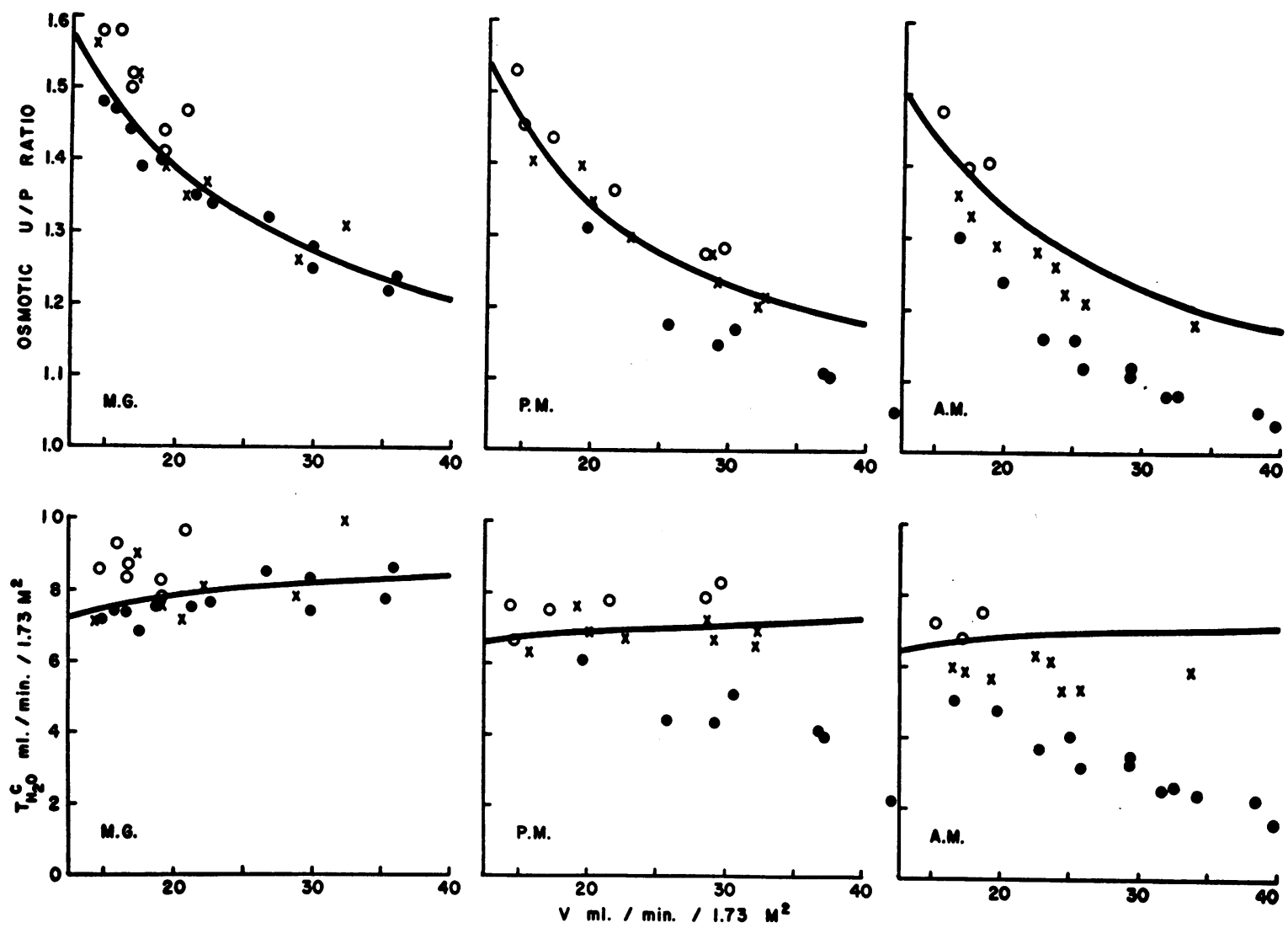

Fig. 3. Concentrating Response at High Urine Flows

Symbols as in Figure 1. Curves continued from those of Figure 1.

tive and might be the result of still other mechanisms than the two described above.

Berliner, Levinsky, Davidson and Eden (5) have postulated that the collecting duct is permeable to urea, so that the urinary urea can be osmotically balanced by urea which has passively diffused into the medullary interstitial fluid. This circumstance should result in enhanced concentrating ability during urea diuresis since the sodium chloride which is presumably actively

TABLE III

Plasma and urine composition at peak urine flow during various types of loading in subjects $M . C ., P . M$. and $A . M .^{*}$

\begin{tabular}{|c|c|c|c|c|c|c|c|}
\hline \multirow[b]{2}{*}{ Type of loading } & \multirow[b]{2}{*}{ Posm } & \multirow[b]{2}{*}{ Purrea } & \multirow[b]{2}{*}{$\mathbf{P}_{\operatorname{man}}$} & \multirow[b]{2}{*}{$\mathbf{P}_{\mathrm{Na}}$} & \multicolumn{3}{|c|}{ Per cent of urine osmolality } \\
\hline & & & & & Urea & Mannitol & $\mathrm{Na} \times 2$ \\
\hline Intermediate flow & $m O s m / K g$ & mMoles/L. & mMoles/L. & $m E q . / L$ & & & \\
\hline $\begin{array}{l}\text { Urea } \\
\text { Mannitol }\end{array}$ & $\begin{array}{l}312 \\
287\end{array}$ & $\begin{array}{r}25 \\
5\end{array}$ & $\begin{array}{r}0 \\
23\end{array}$ & $\begin{array}{l}134 \\
126\end{array}$ & $\begin{array}{l}69 \\
15\end{array}$ & $\begin{array}{r}0 \\
56\end{array}$ & $\begin{array}{l}28 \\
26\end{array}$ \\
\hline High flow & & & & & & & \\
\hline $\begin{array}{l}\text { Urea plus mannitol } \\
\text { Isotonic mannitol } \\
\text { Hypertonic mannitol }\end{array}$ & $\begin{array}{l}329 \\
299 \\
311\end{array}$ & $\begin{array}{r}36 \\
5 \\
4\end{array}$ & $\begin{array}{l}31 \\
70 \\
57\end{array}$ & $\begin{array}{r}111 \\
96 \\
117\end{array}$ & $\begin{array}{r}36 \\
4 \\
3\end{array}$ & $\begin{array}{l}35 \\
66 \\
66\end{array}$ & $\begin{array}{l}28 \\
26 \\
28\end{array}$ \\
\hline
\end{tabular}

* Mean values are given for plasma osmolality $\left(\mathrm{P}_{\mathrm{osm}}\right)$, urea $\left(\mathrm{P}_{\mathrm{urea}}\right)$, mannitol $\left(\mathrm{P}_{\mathrm{man}}\right)$ and sodium $\left(\mathrm{P}_{\mathrm{Na}}\right)$, and for the per cent of urine osmolality contributed by urea, mannitol and sodium with its anion $(\mathrm{Na} \times 2)$. 
concentrated in the medullary interstitial space would be free to balance other solutes than urea. In the present experiments, it was not possible to differentiate the responses to urea and to isotonic mannitol loading at intermediate flows despite marked differences in urinary urea concentration. The finding that chronic (21) and acute (22) urea administration can enhance concentrating ability in protein depleted subjects could be explained by an increase in the amount of urea which enters the medullary interstitial space through Henle's loop, either passively or actively (8). In the present study when urine flow was increased by adding urea to an infusion of isotonic mannitol maintained at $20 \mathrm{ml}$. per minute, there was an increase in $\mathrm{T}^{\mathrm{c}}{ }_{\mathrm{H} 2 \mathrm{O}}$. On the other hand, when much higher rates of urine flow were attained by increasing the rate of isotonic mannitol infusion, $\mathrm{T}^{\mathrm{c}} \mathrm{H}_{2} \mathrm{O}$ decreased. These findings could indicate that an effect of urea could only be detected at high flows when urea concentration was markedly decreased with mannitol loading alone. In addition, the difference between isotonic mannitol and urea loading at high flows appeared to be at least in part ascribable to differences in the osmolality or the volume of the fluid administered, since hypertonic mannitol infusion did not cause the decrease in $\mathrm{T}^{\mathrm{c}}{ }_{\mathrm{H}_{2} \mathrm{O}}$ which occurred with isotonic mannitol loading. The data of Zak, Brun and Smith (4) also show that $\mathrm{T}^{\mathrm{c}_{\mathrm{H}_{2} \mathrm{O}}}$ decreased progressively with increasing flow in five of their seven experiments with isotonic mannitol loading. A progressive decrease in $\mathrm{T}_{\mathrm{H}_{2} \mathrm{O}}$ at very high flows need not represent a decrease in actual rate of water reabsorption at the concentrating site. Micropuncture studies in the rat show that during antidiuresis the fluid entering the distal tubule is hypotonic to the plasma and only gradually becomes isotonic as it passes through the distal tubule (23). At very high flows, this osmotic equilibration might be incomplete so that hypotonic fluid is delivered to the concentrating site. The difference between the responses to isotonic and hypertonic mannitol loading in the present experiments suggests that acute expansion of extracellular fluid volume might decrease concentrating activity; however, large infusions of isotonic sodium chloride have not impaired concentrating ability acutely at lower urine flows (24).

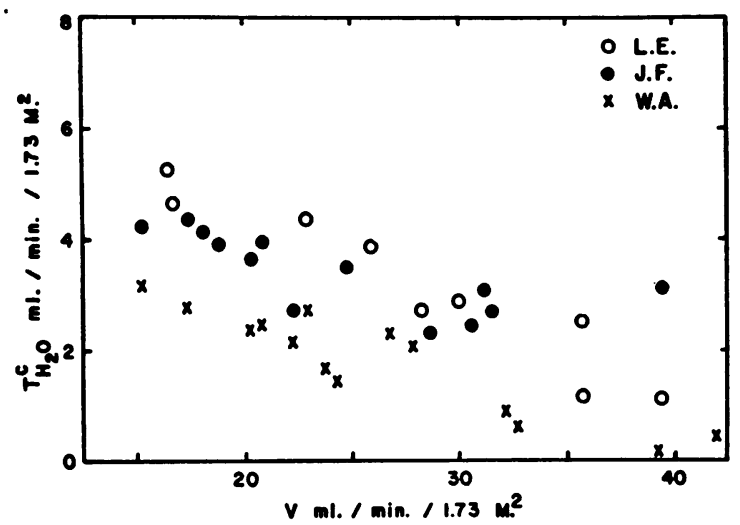

Fig. 4. Concentrating Response to Isotonic Mannitol Loading at High Urine flows on Three AddTIONAL SUBJECTS

In W. A. and J. F. higher values of $\mathrm{T}^{\circ} \mathrm{B}_{2} \mathrm{O}$ were obtained during slow mannitol loading (see Table I).

\section{SUMMARY}

Renal concentrating ability during osmotic diuresis has been examined over a wide range of urine flow in hydropenic normal men. As urine flow (V) increased up to $20 \mathrm{ml}$. per minute per $1.73 \mathrm{M} .^{2}$ there was a curvilinear increase in net water reabsorption $\left(\mathrm{T}^{\mathrm{c}} \mathrm{H}_{2} \mathrm{O}\right)$ and a curvilinear decrease in osmotic urine/plasma $(\mathrm{U} / \mathrm{P})$ ratio, which fit the equation $\frac{1}{\mathrm{U} / \mathrm{P}-1}=a V+b$, where $a$ and $b$ are constants related to maximum net water reabsorption and maximum $\mathrm{U} / \mathrm{P}$ ratio, respectively. Data obtained with urea and mannitol loading at intermediate flows fit this equation and showed no difference between the responses to the two solutes.

When urine flow was increased up to $40 \mathrm{ml}$. per minute per $1.73 \mathrm{M}^{2}$, this relationship was disrupted. $\mathrm{T}^{\mathrm{c}_{\mathrm{H}_{2} \mathrm{O}}}$ usually decreased progressively with isotonic mannitol loading. Concentrating ability was greater with urea plus mannitol loading at these urine flows than with isotonic mannitol alone, while the response to hypertonic mannitol loading was intermediate.

\section{REFERENCES}

1. McCance, R. A. The excretion of urea, salts, and water during periods of hydropaenia in man. J. Physiol. (Lond.) 1945, 104, 196.

2. Rapoport, S., Brodsky, W. A., West, C. D., and Mackler, B. Urinary flow and excretion of solutes during osmotic diuresis in hydropenic man. Amer. J. Physiol. 1949, 156, 433. 
3. Raisz, L. G., and Scheer, R. L. Studies on the renal concentrating mechanism. II. Effect of small acute changes in solute excretion. J. clin. Invest. 1959, 38, 1.

4. Zak, G. A., Brun, C., and Smith, H. W. The mechanism of formation of osmotically concentrated urine during the antidiuretic state. J. clin. Invest. 1954, 33, 1064.

5. Berliner, R. W., Levinsky, N. G., Davidson, D. G., and Eden, $M$. Dilution and concentration of the urine and the action of antidiuretic hormone. Amer. J. Med. 1958, 24, 730.

6. Kellogg, R. H., and Koike, T. I. Difference between mannitol and urea diuresis in the rat (abstract). Amer. J. Physiol. 1955, 183, 633.

7. Rubini, M. E., Blythe, W. B., and Meroney, W. H. Effect of the type of urinary solute on the process of urine concentration (abstract). J. clin. Invest. 1957, 36, 926.

8. Schmidt-Nielsen, B. Urea excretion in mammals. Physiol. Rev. 1958, 38, 139.

9. Hilger, H. H., Klümper, J. O., and Ullrich, K. J. Wasserrückresorption und Ionentransport durch die Sammelrohrzellen der Säugetierniere. Pflüg. Arch. ges. Physiol. 1958, 267, 218.

10. Snedecor, G. W. Statistical Methods. 5th ed. Ames, Iowa, Iowa State College Press, 1956, p. 534.

11. Lineweaver, H., and Burk, D. The determination of enzyme dissociation constants. J. Amer. chem. Soc. 1934, 56, 658.

12. Raisz, L. G., Au, W. Y. W., and Scheer, R. L. Studies on the renal concentrating mechanism. III. Effect of heavy exercise. J. clin. Invest. 1959, 38, 8.

13. Raisz, L. G., Au, W. Y. W., and Scheer, R. L. The relationship between net water reabsorption and osmolal clearance as a measure of renal-concentrating activity (abstract). Clin. Res. 1958, 6, 284,

14. Wirz, H., Hargitay, B., and Kuhn, W. Lokalisation des Konzentrierungsprozesses in der Niere durch direkte Kryoskopie. Helv. physiol. pharmacol. Acta 1951, 9, 196.

15. Wirz, H. The location of antidiuretic action in the mammalian kidney in The Neurohypophysis, Proc. Eighth Symp. Colston Research Soc., H. Heller, Ed. New York, Academic Press, 1957, p. 157.

16. Ullrich, K. J., and Jarausch, K. H. Untersuchungen zum Problem der Harnkonzentrierung und Harnverdünnung. Pflüg. Arch. ges. Physiol. 1956, 262, 537.

17. Ullrich, K. J. Aktiver Natriumtransport und Sauerstoffverbrauch in der äusseren Markzone der Niere. Pflüg. Arch. ges. Physiol. 1958, 267, 207.

18. Rutgers, A. J. Physical Chemistry. New York, Interscience Publishers, 1954, p. 370.

19. Stetten, D., Jr. Relationship of hormone dosage to physiological response. Science 1956, 124, 365.

20. Babbitt, J. D. Osmotic pressure. Science 1955, 122, 285.

21. Epstein, F. H., Kleeman, C. R., Pursel, S., and Hendrikx, A. The effect of feeding protein and urea on the renal concentrating process. J. clin. Invest. 1957, 36, 635.

22. Levinsky, N. G., and Berliner, R. W. The role of urea in the urine concentrating mechanism. J. clin . Invest. 1959, 38, 741 .

23. Wirz, H. Der osmotische Druck in den corticalen Tubuli der Rattenniere. Helv. physiol. pharmacol. Acta 1955, 14, 353.

24. Au, W. Y. W., and Raisz, L. G. The impairment of renal-concentrating ability during mercurial diuresis (abstract). Clin. Res. 1959, 7, 280. 